\title{
A NOTE ON PALEY AND HIS SCHOOL - WAS SIR LESLIE STEPHEN MISTAKEN?
}

\section{Graham Cole}

Though once described as one of Cambridge's heroes, these days few bother to recall William Paley, Archdeacon of Carlisle. 1 Those who do are usually in specialist areas of academia. Those, for example, interested in the history of Christian Apologetics remember Paley as an outstanding (even if no longer convincing) example of eighteenth century evidence writing. Others concerned with the history of science recall Paley as one of those windows through which one may glimpse the role of teleological explanations in the English Enlightenment period. Still others, whose penchant is the study of Natural Theology, find Paley of interest because he gave quintessential expression to one of the classic arguments for God's existence: namely, the Design Argument centred on the analogy between a watch and the world on the one hand, and between a watchmaker and a putative worldmaker on the other. Finally, for historians of ethical thought Paley represents the clearest exponent of theological utilitarianism and the anticipator of Jeremy Bentham's own secularized version. 2

For those who want a more general introduction to Paley's thought, the place to begin with is still considered to be Sir Leslie Stephen's pioneering work in the history of ideas English Thought in the Eighteenth Century. ${ }^{3}$ However, to

1 See G. W. Meadley, Memoirs of William Paley, D.D. (Sunderland, 1809) 199.

2 On Paley and apologetics see A. Dulles, A History of Apologetics (London, Hutchinson 1971); on natural theology see W. P. Alston, 'Paley', in P. Edwards (ed.), The Encyclopaedia of Philosophy VII (N.Y., Macmillan 1967) 84-8; on the history of science see J. H. Brooke in New Interactions between Theology and Natural Sciences (Milton Keynes, 1974) Units 9-10, Open University; and on the utilitarian tradition see J. B. Schneewind, Sidgwick's Ethics and Victorian Moral Philosophy (Oxford, Clarendon 1977).

3 For example, see V. F. Storr, The Development of English Theology in the Nineteenth Century 1800-1860 (London, Longmans, Green \& Co 1913), chapter III, especially 27, note 1 . And for more recent examples see F. Ferré, Natural theology - Selections (N.Y., The Bob Merrill Co. 1963) xxxiii; M. L. Clarke, Paley: Evidences for the Man (London, SPCK 1974), especially the endnotes 148-50; D. L. Le Mahieu, The Mind of William Paley (Lincoln and 
Stephen (1832-1904), Paley was definitely not one of Cambridge's heroes and nor were two of his contemporaries John Hey (1734-1815), the first Norrisian Professor at Cambridge and Richard Watson (1737-1816), Bishop of Llandaff, who at one stage was himself Professor of Divinity at the same university.4

Stephen's account of Paley is open to criticism at a number of levels; one of which is the concern of this note. For in his highly influential English Thought in the Eighteenth Century, Stephen links William Paley with John Hey and with Richard Watson under the head of Paley and His School'.5 He notes that all were Cambridge men, nearly contemporary there and wranglers of the university. He also describes their theological views as 'the Cambridge School', the starting point of which lay in Bishop Edmund Law's Considerations on the Theory of Religion published in 1745 and reprinted many times after. He further notes that Law, Paley and Watson spent their formative years in the North country. 6

Stephen takes Paley's 'system' as representative of the school: a dependence upon the teleological argument for God's existence and an appeal to miracle to justify belief in Christianity as a revealed religion.7 Again, he takes Paley as representative of 'an important peculiarity' of 'Paley and His School', namely, here were men who sat lightly on 'some of the dogmas of his professed creed'. According to Stephen, the logic 'of Paley's position [and presumably that of Hey and Watson] leads to Unitarianism' .8

Elsewhere in the first volume, Stephen maintains that Paley and Hey shared 'almost identical' theologies. Hey, he argues, held such an attenuated doctrine of the Trinity that it was Tittle more than an ostensible badge of churchmembership'.9 Hey had argued that he differed from

London, University of Nebraska Press 1976) 2 and 185 especially.

4 On Stephen himself see Noel Annan, The Godless Victorian (Chicago and London, University of Chicago Press 1986).

5 See Leslie Stephen, English Thought I (London, Smith, Elder and Co. 31902) 405-20.

6 Ibid. passim.

7 Ibid. 408-9, especially.

8 Ibid. 420. 
Socinians not over morality, nor natural religion, nor over the divine authority of the Christian religion, but over what 'we do not understand' (namely, the nature of the godhead).10 Stephen's sarcasm is stinging:

He [Hey], in fact, holds with the deists, that talk about the Trinity is little better than unmeaning gibberish, but, unlike them, he considers that to be a reason for using it. Why baulk at such a trifle? ... The morality, doubtful in any case, could only pass muster when the leading divines of the time had become profoundly indifferent to the tenets thus undermined. The intellectual party of the church [presumably Paley and Watson included] was Socinian in everything but name. 11 (My emphasis)

Stephen's contempt is patent. On his view Paley, Watson and Hey were 'only nominal Trinitarians'. They remained within 'orthodoxy' solely because 'they attached too little importance to their dogmas to care for a collision with the Thirty-nine articles.' 12

'The Cambridge School', 'Paley and His School' and 'the intellectual party of the church' are Stephen's own expressions and suggest that he saw in Paley, Watson and Hey a self-conscious group, united in idea and purpose within the established church. But were they?

Even if by 'Paley and His School', Stephen meant simply Paley and his ilk (that is those sharing a common set of beliefs and values consciously or unconsciously), then his designation is still quite misleading. For example, Watson was critical of some of both Paley's ethical and political stances.13 And if Bishop Edmund Law is to be seen as the starting point of the school, then again, Paley held to the doctrine of Christ's pre-existence; whilst Law came to reject it. 14

9 Ibid. 424.

10 lbid.

11 lbid. 426.

12 Ibid. 421.

13 See the account in R. Lynam's introduction to The Works of William Paley, I (London, 1823), there are some ethical and political principles [note] in his philosophy which I by no means approve'.

14 Paley's sermons contain unequivocal affirmations of Christ's preexistence. See, for example, J. Paxton (ed.), The Works of William Paley, V (London, 1845) 165, 'that such a person should come down from heaven' and for Law's later position see Anonymous' note in William Paley, A Short Memoir of $E$ Law, $D D$. (Chancery Lane, 1800) 10 in which Law describes 
Further, if by school Stephen had in mind a group bound together not only by ideas, but by personal ties; then he failed to note that Paley and Watson, for example, had little or no contact after Cambridge. Indeed, Paley who was generally sanguine and accommodating, had a hearty dislike of Watson. 15 A like commitment to reform on the subscription issue, a tolerant attitude towards dissenters and a dislike of over-systematized theology do not constitute a school. 16

On the matter of 'nominal Trinitarianism', Stephen is mistaken in the cases of Hey and Paley, but not Watson. Paley could preach on the unity of God in the following terms:

We hear, nevertheless, of three divine persons - we speak of Trinity. We read of the 'Father, Son and Holy Ghost'. Now concerning these, it is to be observed, that they must all be understood in such a manner as to be consistent with the above declarations, that three is 'one only supreme God'. What is that union which subsists in the divine nature, of what kind is that relation by which the divine persons of the Trinity are connected, we know little - perhaps it is not possible that we should know more; but this we seem to know, first, that neither man nor angel bears the same relation to God the Father as that which is attributed to his only begotten Son, our Lord Jesus Christ; and secondly, that very thing does not break in upon the fundamental truth of religion; that three is 'one only supreme God'. . . (My emphasis). 17

This is neither Socinian, nor Arian. The reticence to speak of the Quid est of God (in contradistinction to the Qualis sit ) is traditional. Aquinas would have endorsed the modesty of the statement and its awareness of epistemic limitations. Yet, Paley clearly affirms both the unity of the Godhead and the plurality of the 'divine persons'. And importantly, the Spirit is included amongst the divine persons. ${ }^{18}$

the doctrine of Christ's pre-existence as an 'ancient prejudice' now purged from his Theory of Religion.

15 See M. L. Clarke, Paley: 8.

16 Others at Cambridge in the last part of the century also had a strong dislike of over-systematizing, even though their churchmanship was very different from that of Watson, Hey and Paley. Charles Simeon is a case in point. See H. E. Hopkins, Charles Simeon of Cambridge (London, Hodder \& Stoughton 1977), especially chapter eleven.

17 Sermon XXVII in E. Paley (ed.), Sermons on Various Subjects II (London, 1825) 273.

18 Also see Paley's sermon, 'Evil Propensities Encountered By the aid of the 
With regard to John Hey, again Stephen is mistaken. For Hey too affirmed a Trinitarian position. He did so publicly and in conscious awareness that many 'dissenting brethren, men learned and estimable' would regard his position as repugnant to the New Testament, because he was prepared to affirm the Athanasian Creed. 19 Hey, however, argued that the Athanasian Creed (anathemas excepted) was both 'Scriptural' and 'perfect. According to Hey, the creed does not attempt to explain the mysteries of the Trinity and Incarnation, but to state them. As well, the creed designedly seeks to exclude certain real errors (Apollinarianism, Nestorianism and Eutychianism, for example). ${ }^{20}$ Again, this is neither Socinianism nor Arianism, but a cautious orthodoxy sensitive to the difficulties felt by dissent in an area of doctrinal mystery.

Moreover, in Hey's Lectures in Divinity - the very work cited by Stephen - the first Norrisian Professor states categorically:

I believe many have a notion, that the doctrine of the Trinity is formed in an arbitrary and presumptuous manner, by going beyond what is revealed and taking human imaginations for divine instructions or commands. My notion differs from this: I believe that the Scripture is the source of the Doctrine in every part. 21

On the very next page he affirms that the doctrine of the Trinity makes best sense of 'all expressions of Scripture' with regard to the divine attributes. 22 Strange Socinianism this.

A note is not the place to present at any length a detailed exposition of either Paley or Heys' Trinitarianism. The foregoing should be sufficient to show that neither Paley nor Heys' doctrinal stance should be dismissed as glibly as Stephen's does as 'Socinian in everything but name'. Nor should diffidence about doctrinal precision be interpreted as disingenuous and barely hiding 'a rationalism thinly concealed'.23

19 See his sermon, Thoughts on the Athanasian Creed (Cambridge, 1790), 7.

20 Ibid., especially 8, 11, 13.

21 John Hey, Lectures in Divinity II (Cambridge, 1797) 244.

$\mathfrak{2}_{\text {I }}$ bid. 245.

23 See Stephen, English Thought II 124 and compare with Hey on diffidence: 'It is only expressing a temper, which has been recommended as 
As regards Watson - he defended Unitarianism as essentially Christian. Moreover, he denied that Athanasian Trinitarianism 'is literally contained in any passage of Holy Writ, or can by sound criticism be deduced from it'.24 Stephen is on firmer ground then, when he describes Watson's Trinitarianism as nominal, but not so with regard to Paley and Hey.

In conclusion, Stephen's account of 'Paley and His School' is either mistaken or highly misleading. For on scrutiny important differences emerge between Watson, Hey and Paley (and, for that matter, Law himself) on a range of issues in the fields of doctrine and ethics. On ethical and political ideas Watson disagreed with Paley. 25 On doctrine Law differed from Paley on the question of Christ's preexistence and Hey differed from Watson on the Athanasian doctrine of the Trinity. Furthermore as far as personal contact was concerned, there is little or no evidence of such contacts between Watson and Paley after their early Cambridge days. Given this range of evidence Stephen's designations 'the Cambridge school', 'the intellectual party of the church' and 'Paley and His School' appear dubious in the extreme.

always proper in the discussion of doctrine above human comprehension' in his Lectures II 213. Stephen in his treatment of Hey only refers to the first volume.

24 Quoted in N. Sykes, The English Religious Tradition (London, SCM 1933) 62. Also see Sykes, Church and State in England In the XVIIIth Century (Cambridge, Cambridge University Press 1934), 350- 4.

25 Interestingly, according to John Law, his father Edmund Law was also at variance with Paley on some important ethical matters, so the son delayed the publication of Paley's Principles of Moral and Political Philosophy for some ime. See the account in Clarke, Paley 41. 